\title{
Riccardo Saccenti \\ The Reception of the Summa Halensis in the Manuscript Tradition until 1450
}

\begin{abstract}
The survival of a large number of manuscripts of the Summa Halensis allows scholars to gain an understanding of the multiple frameworks and cultural environments in which this text was received, from its composition in the 1240s to the first printed edition at the end of the 15th century. This chapter peruses the manuscripts of the Summa with a view to assessing the process of the text's composition and circulation. The study takes into account multiple dimensions of the text's reception, including the historical development of theology in the early decades of the 13th century; the process of the composition of theological writings; the material production of manuscripts within the university milieu and the institutionalization of the so-called pecia system; and the various ways in which theological texts were used in the university and in the convents of the religious orders. All these elements help to reconstruct the circulation of the Summa.
\end{abstract}

In 1474 the German merchant John of Cologne created a new commercial partnership with another German businessman, Johannes Manthen. ${ }^{1}$ The new company was based in Venice where John of Cologne had travelled for work since 1468: in fact, in that same year he is registered in Cologne as a Hansa merchant who traded Italian goods such as Venetian glass and luxury products. In 1471 John engaged in a new kind of profitable activity: he formed a partnership with Wendelius of Spira who had taken over the printing business from his brother Johannes. After Wendelius' death in 1473, John of Cologne decided to carry on with the production of printed books, which was rapidly becoming a growing economic sector and had found a quite favorable cultural and economic environment in Italy, and particularly in Venice.

In the same year as its creation, 1474, the new company Johannes de Colonia sociusque eius Johannes Mantheni printed what was titled 'the solemn work of master Alexander of Hales, a highly renowned theologian of the order of the Minors, on the third book of the Sentences.' ${ }^{2}$ The following year the company twice reprinted the book attributed to Alexander of Hales, which was in fact the third part of the

\footnotetext{
1 See Christian Coppens, 'Giovanni da Colonia, aka Johann Ewylre/Arwylre/Ahrweiler: The Early Printed Book and its Inventions,' La Bibliofilia 116 (2014), pp. 113-20. See also Angela Nuovo, The Book Trade in the Italian Renaissance (Leiden; Boston: Brill, 2013). See also Martin Lowry, 'The Social World of Nicholas Jenson and John of Cologne,' La Bibliofilia 83 (1981), pp. 193-218.

2 Alexander of Hales, Super Tertium Sententiarum (Venice: Johannes de Colonia et Johannes Manthen, 1474).
}

D OpenAccess. (c) 2021 Riccardo Saccenti, published by De Gruyter. (cc) BY-NC-ND This work is licensed under the Creative Commons Attribution-NonCommercial-NoDerivatives 4.0 License. 
Summa fratris Alexandri. Six years later, the prestigious German printing company of Anton Koberger in Nuremberg started the publication of the entire Summa under the title of Summa universae theologiae, the first volume of which was printed on the 24th of January 1481, while the printing of the fourth and last book was accomplished on 23 August 1482. ${ }^{3}$ In 1489 another important printing company, the one created in Pavia by Francesco Girardenghi and Giovanni Antonio Berretta, published the entire Summa fratris Alexandri as a result of an editorial project financially supported by the noble lady Franceschina Beccaria. ${ }^{4}$

This rapid survey shows that from the first printing in 1474 to the end of the 15th century, the Summa was edited three times, and on several occasions these editions were also reprinted. ${ }^{5}$ This suggests the existence of a strong interest in this work attributed to Alexander of Hales within the intellectual milieu of the time. More specifically, the advantages of the printed book as a means to increasing the circulation of a text matched the cultural appeal of some specific writings within a different disciplinary field. Still, in the late 15th century, that is, in the flourishing years of Humanism and Renaissance, the great Franciscan theological Summa was read and studied among theologians together with other medieval 'classics', such as Aquinas' Summa Theologiae. The central place of the Summa fratris Alexandri in the ideal theological library of the late Quattrocento can be seen both as a turning point and as a final achievement in the history of the diffusion of this text: the printing improved the already consistent circulation of the Summa, but at the same time, it changed it, because it inserted this text into a new kind of approach to the written text. ${ }^{6}$

3 Alexander of Hales, Summa Universae Theologiae: Pars 1-4 (Nuremburg: Anton Koberger, 1481-82). On Koberger see Oskar van Hase, Die Koeberger: Eine Darstellung des buchländlerischen Geschäftsbetriebes in der Zeit des Überganges von Mittelalter zur Neuzeit, 2 vols (Leipzig: Breikopf \& Härtel, 1885); Ferdinand Geldner, Die deutschen Inkunabeldrucker, 2 vols (Stuttgart: Hiersemann, 1968), vol. I, pp. 162-67; Adrian Wilson and Joyce L. Wilson, The Making of the Nuremberg Chronicle (Amsterdam: Nico Israel, 1976), pp. 175 - 79; Janet I. Freeman, 'Anton Koberger's First Books: Paper Stocks and Sequence of Printing,' The Princeton University Library Chronicle 55 (1994), pp. 308-22.

4 Alexander of Hales, Summa Theologica: Pars 1- 4 (Pavia: Joannemantonius de Brirretis et Franciscus Gyrardengus, 1489). See also Arnaldo Ganda, 'Girardenghi Francesco,' in Dizionario Biografico degli Italiani (Rome: Istituto dell'Enciclopedia Italiana, 2001), vol. 56, online at http://www.trecca ni.it/enciclopedia/francesco-girardenghi_(Dizionario-Biografico)/; Alfredo Cioni, 'Beretta, Giovanni Antonio,' in Dizionario Biografico degli Italiani (Rome: Istituto dell'Enciclopedia Italiana, 1967), vol. 9, pp. 51-53, online at http://www.treccani.it/enciclopedia/giovanni-antonio-beretta_\%28Dizio nario-Biografico\%29/; Anna G. Cavagna, 'Una operazione editoriale a Pavia a fine Quattrocento: Il caso Beretta-Girardengo-Beccaria,' Bollettino della società pavese di storia patria 82 (1982), pp. 48 -58; Tullia Gasparrini Leporace, 'La società tipografica Bretta-Girardengo (1479-1492) nei documenti inediti coevi,' La Bibliofilia 50 (1948), pp. 24-52; Enea Gualandi, 'La tipografia di Pavia nel secolo XV,' Bollettino della società pavese di storia patria 59 (1959), pp. 43-83.

5 For a general survey on the printed editions of the Summa Halensis see Irenaeus Herscher, 'A Bibliography of Alexander of Hales,' Franciscan Studies 5 (1945), pp. 434-54.

6 Some essential remarks on the connection between the early printed editions and the manuscript tradition of the Summa are offered in the contribution of William Courtenay in this present volume. 
The survival of a great number of manuscripts of the four parts of the Summa allows us to set up an enquiry on the multiple frameworks and cultural environments that this text went through, offering a unique perspective on its nature and value in the later middle ages. The history of a work certainly consists in its origin and the intentio auctoris, but it also involves of its reception. As the studies of the Quaracchi editors have already clarified, the 'reception' of the Summa fratris Alexan$d r i$ was linked to the composition of its four parts. ${ }^{7}$ Moreover, precisely this early mix and overlapping of composition and reception influenced both the development of the 'editorial' enterprise and the way it was received within its intellectual context, particularly among the theologians. In the long run, however, it also affected the realization of the modern printed editions, whose textual differences depend on the manifold manuscript tradition of each part of the Summa.

Therefore, using as a starting point the precious work done by the Quaracchi editors between the 1920s and the 1940s, a study of the manuscripts of the Summa becomes a means of assessing the process of the text's composition and circulation. Certainly, this kind of research requires the scholar to take into account multiple factors: the historical development of theology as a discipline in the early decades of the 13th century; the composition of the theological writings in this same period, based on sources and materials which are linked with the scholarly activities of a master; the material production of manuscripts within the university milieu; the institutionalization of the so-called pecia system; and the multiple ways in which theological texts were circulated and used in the university, the network of convents of the religious orders, and in private libraries.

By considering all these elements, this contribution aims to deepen understanding of the circulation of the Summa fratris Alexandri and the influence of this Franciscan text, particularly in the second half of the 13th century. In fact, moving through the manuscript tradition and focusing on some key manuscripts makes it possible to offer a survey of the different roles that the Summa assumed in the theological field in the decades from the early 1240 s to the beginning of the 14 th century.

\footnotetext{
A closer analysis of this issue, mainly focused on book IV of the Summa, will be the subject in a forthcoming study. What emerges from the preliminary results of this examination, and Prof. Courtenay's research confirms, is that the Koberger edition introduced the structure according to quaestiones, articuli and membra, which will remain as the major set up of the Summa but is not present in the manuscripts.

7 See Victorin Doucet, Prolegomena in librum III necnon in libros I et II Summae Fratris Alexandri, in Alexander of Hales, Doctoris irrefragabilis Alexandri de Hales Ordinis minorum Summa theologica (SH), 4 vols (Quaracchi: Collegium S. Bonaventurae, 1924-48), IV, Tome A; idem, 'The History of the Problem of the Authenticity of the Summa,' Franciscan Studies 7 (1947), pp. 26-41, 274-312; idem, 'De Summa fratris Alexandri Halensis historice considerata,' Rivista di filosofia neo-scolastica 40 (1948), pp. 1-44; idem, 'Autour des Prolegomena ad Summam fratris Alexandri,' Archivum Franciscanum Historicum 43 (1950), pp. 196-200; Igantius Brady, 'The Summa Theologica of Alexander of Hales (1924-1928),' Archivum Franciscanum Historicum 70 (1977), pp. 434-47; Bernhard Geyer, 'Der IV. Band der Summa des Alexander Halensis,' Franziskanische Studien 31 (1949), pp. 1-14.
} 
The development of the Franciscan life in Paris, and specifically in the university, offers the general cultural framework for studying the manuscripts so that these fragments of the now lost picture of the late medieval understanding of the intellectual monument which is the Summa fratris Alexandri can become the subject of a sort of restoration.

\section{Learning and the Franciscans}

Written between 1267 and 1268, Roger Bacon's Opus Minus contains a famous yet severe critique of Parisian theology. ${ }^{8}$ The author, who in 1255 had joined the order founded by Francis of Assisi, underscores the problems with the attitude of the Parisian masters towards theology. He notes that they lack the knowledge of key disciplines such as mathematics, and that they frequently subordinate theological discourse to philosophical reasoning. In addition, the Parisian faculty of theology is the place where lecturing on the Sentences overtook lecturing on Scripture, was skewing the teaching priorities of theologians. Bacon adds that such a questionable theological approach grew up in Paris because of the distorted reception of the thought and method of two notorious figures whose mastery was overestimated by their contemporaries. The first of these Parisian masters was Alexander of Hales, who was firstly archdeacon and secular master, and later joined the Franciscan Order in 1236, becoming the veritable intellectual authority among the Minor Friars. Bacon explains:

At that time the order of the Minors was young and neglected by mankind, and he [i.e. Alexander] edified the world and exalted the order. Since his joining, the friars and others praised him to the heavens and gave him authority over the whole intellectual education and ascribed to him that great Summa which is too heavy a burden for a single horse, and that he himself did not

8 Roger Bacon, Opus Minus, in Fratris Rogeri Bacon Opera quaedam hactenus inedita, ed. J.S. Brewer (London: Longman, Green, Longman, and Roberts, 1859), pp. 311-90. On Roger Bacon and his engagement with the development of the Franciscans, see William J. Courtenay, 'Franciscan Learning: University Education and Biblical Education,' in Defenders and Critics of Franciscan Life: Essays in Honour of John V. Flemming, eds. M.F. Cusato and G. Geltner (Leiden: Brill, 2009), pp. 55-64; Roger Bacon and the Sciences: Commemorative Essays, ed. J. Hackett (Leiden: Brill, 1997); Timothy J. Johnson, 'Roger Bacon's Critique of Franciscan Preaching,' in Institution and Charisma: Festschrift für Gert Meville, eds. F.J. Felten, A. Kehnel, and S. Weinfurter (Vienna: Böhlau, 2009), pp. 541-48; idem, Franciscans and Preaching (Leiden: Brill, 2012); Bert Roest, A History of Franciscan Education (c. 1210-1517) (Leiden: Brill, 2000); idem, 'The Franciscan School System: Re-assessing the Early Evidence (ca. 1220-1260),' in Franciscan Organization in the Mendicant Context: Formal and Informal Structures of the Friars' Lives and Ministry in the Middle Ages, eds. M. Robson and J. Roehrkasten (Berlin: Lit, 2010), pp. 253-79. 
make but others did. However, it was ascribed to him out of respect and it was called the Summa fratris Alexandri. ${ }^{9}$

Beyond the critical tone of the text, Bacon's quotation offers some useful insights for reconstituting the historical and cultural context, namely, that of the Parisian university in the second quarter of the 13th century, in which the Summa first came into the light. In fact, Alexander of Hales' joining of the order marked a turning point in the relationship between the Franciscans and the university. ${ }^{10}$ This latter is the place where theology prepared to definitively assume the contours of a science, and it represents an institution which had the status of a guild of masters and students. Within this context, the daily scholastic activity had a predominantly oral form, based on the study and interpretation of textual corpora which fused together teaching and doctrinal development. From the beginning of the 13th century a complex process had determined the evolution of the teaching of theology in Paris. Robert of Courçon's statutes in 1215 and Gregory IX's bull Parens scientiarum in 1231 can be seen as the major witnesses to this progressive attempt to define the specific epistemological features of theology and to establish a proper pedagogical framework for its teaching in Paris. ${ }^{11}$

The university inherited the practices of the late 12th-century schools, particularly those established within the cathedral chapter of Notre Dame and descending from the mastery of Peter Lombard. The notorious threefold distinction between lec-

9 Roger Bacon, Opus Minus, ed. Brewer, p. 236: 'Novus fuit ordo Minorum et neglectus a mundo illis temporibus, et ille aedificavit mundum et ordinem exaltavit. Ex suo ingressu fratres et alli exaltaverunt in coelum, et ei dederunt auctoritatem totius studii, et adscripserunt ei magnum Summam illam, quae est plusquam pondus unius equi, quam ipse non fecit sed alii. Et tamen propter reverentiam ascripta fuit, et vocatur Summa fratris Alexandri.'

10 See Neslihan Senocak, The Poor and the Perfect: The Rise of Learning in the Franciscan Order, 1209-1310 (Ithaca; London: Cornell University Press, 2012); Hubert P. Weber, Sünde und Gnade bei Alexander von Hales: Ein Beitreg zur Entwicklung der theologischen Anthropologie im Mittelalter (Innsbruck: Tyrolia, 2003), pp. 11-41; Marco Arosio, Aristotelismo e Teologia da Alessandro di Hales a San Bonaventura (Rome: Liamar, 2012).

11 On this, see Luca Bianchi, 'Les interdictions realtives à l'enseignement d'Aristote au XIII ' siècle,' in L'enseignement de la philosophie au XIII siècle: Autour du "Guide de l'étudiant” du ms. Ripoll 109. Actes du colloque international, eds. C. Lafleur and J. Carrier (Turnhout: Brepols, 1996), pp. 109-37; Stephen J. Williams, 'Repenser l'intention et l'effect des décrets de 1231 du pape Grègoire IX sur l'étude de libri naturales d'Aristote à l'Université de Paris,' in L'enseignement de la philosophie au XIII siècle, eds. Lafleur and Carrier, pp. 139-63; Luca Bianchi, Censure et liberté intellectuelle à l'université de Paris (XIII - XIV siècle) (Paris: Les Belles Lettres, 1999), pp. 103-27; idem, 'Aristotle as a Captive Bride: Notes on Gregory IX's Attitude towards Aristotelianism,' in Albertus Magnus und die Anfänge des Aristoteles-Rezeption im lateinischen Mittelalter: Von Richardus Rufus bis zu Franciscus de Mayronis, eds. L. Honnefelder, R. Wood, H. Dreyer, and M.-A. Aris (Münster: Aschendorff Verlag, 2005), pp. 777-94; Spencer E. Young, Scholarly Community at the Early University of Paris: Theologians, Education and Society 1215-1248 (Cambridge: Cambridge University Press, 2014), pp. 64-101. On Robert of Courçon's intervention in 1215 see Jacques Verger, Culture, enseignement et société en Occident aux XII ${ }^{e}$ et XIII ${ }^{e}$ siècles (Rennes: Presses Universitaires de Rennes, 1999), pp. 120 - 22. 
turing, disputing, and preaching that Peter the Chanter outlined in his Verbum abbreviatum summarizes the different oral practices of a master of theology and provides an image of what the university inherited from the pedagogical development of the 'long 12th century'. ${ }^{12}$ The written witnesses of such diverse oral activities are fixed in the lectures, in the disputed questions and in the sermons. In several cases, both the disputed questions and the sermons are collected in order to provide doctrinal materials, but also to offer useful models for the practice of these oral activities, particularly in the case of sermons. The collections of disputed questions had evolved into the genre of the Summa whose aim was to bring together the fruit of a master's disputing activity according to a specific thematic order usually shaped according to that of Peter Lombard's Sentences. ${ }^{13}$ That text offered contents and examples to theologians for the practice of their own discipline. In the decades between the 12th and the early 13th centuries, this discipline evolved into a certain kind of wisdom and science with its own canon of authoritative sources, including the Bible usually accompanied by the Gloss together with Peter Lombard's Sentences and Peter the Chanter's Historia scholastica. ${ }^{14}$

Roger Bacon's account of Alexander of Hales' joining of the Franciscans and of the composition of the Summa ascribed to him refers to such an historical and cultural framework. This latter can be better understood by mentioning two other historical features which rapidly came to impact the cultural history of the early 13th century. As Herbert Grundmann noted in a still seminal article, whose basic in-

12 See Peter the Chanter, Verbum abbreviatum, I.1, ed. M. Duthion-Boutry (Turnhout: Brepols, 2004), pp. 4-11.

13 See on this Palémon Glorieux, 'L'enseignement au Moyen Âge: Techniques et méthodes en usage à la Faculté de Théologie de Paris au XIII ${ }^{\mathrm{e}}$ siècle,' Archives d'histoire doctrinale et littéraire du Moyen Âge 35 (1968), pp. 65-189; Claire Angotti, 'Le début du Livre des Sentences comme manuel de théologie à l'Université de Paris,' in Université, Église, Culture: L'Université Catholique au Moyen-Âge: Actes du $4^{\text {ème }}$ Symposium Katholieke Universiteit Leuven, 11-14 mai 2005, ed. L. Roche (Paris: Centre de Coordination de la Recherche de la FIUC, 2007), pp. 59-126; Philipp Rosemann, The Story of a Great Medieval Book: Peter Lombard’s 'Sentences' (Peterborough: Broadview Press, 2007); Marcia L. Colish, 'The Sentence Collection and the Education of Professional Theologians in the Twelfth Century,' in The Intellectual Climate of the Early University: Essays in Honor of Otto Gründler, ed. N. Van Deusen (Kalamazoo: Medieval Institute Publications, 1997), pp. 1-26; idem, 'From the Sentence Collection to the Sentence Commentary and the Summa: Parisian Scholastic Theology, 1130 - 1215,' in Manuels, programmes de cours et techniques d'enseignement dans les universités médiévales, ed. J. Hamesse (Louvain-la-Neuve: Institut d’Études Médiévales, 1994), pp. 9-29; Riccardo Saccenti, 'Questions et Sentences: l'enseignement entre la fin du XIIe et le début du XIIIe siècle,' in Les Débuts de l'enseignement universitaire à Paris (1200 - 1245 environ), eds. J. Verger and O. Weijers (Turnhout: Brepols, 2013), pp. $275-93$.

14 See Marta Borgo, 'L’enseignement des Sentences pendant la première moitié du XIIIe siècle,' in Les Débuts de l'enseignement universitaire à Paris, eds. Verger and Weijers, pp. 295-314; Mark J. Clark, The Making of the 'Historia Scholastica', 1150-1200 (Toronto: Pontifical Institute of Mediaeval Studies, 2015); Lesley Smith, The Glossa Ordinaria: The Making of a Medieval Bible Commentary (Leiden; Boston: Brill, 2009). 
tuition was later on developed by John Baldwin, the studium became from the 12th century a veritable power in its own right: ecclesiastical and civil careers required a high-level education. ${ }^{15}$ Knowledge, like kingship and priesthood, had become a source of authority, and the new 'social' status that accompanied it required a juridical form and a recognizable structure. Therefore, as the political potestas and the ecclesiastical auctoritas had their social and legal profiles, so the masters determined their own status. The term studium does not simply designate some cultural practices but refers also to a guild which claimed its own libertas and presented itself as a societas within the economic, social, political, and religious network of Latin Europe.

The presence of new religious orders, especially the Dominicans and the Franciscans, is weaved together with this process of institutionalizing knowledge. Both the Preachers and the Minors offer a religious answer to the evangelical instance that agitated the developing European society and that was rooted above all in the cities, where the schools and the universities were located. The urban context, to which both scholastic culture and the spiritual and religious experience of the Franciscans belonged, was the crossroads of historical tensions and expectations. Therefore, the university, that is, the place where knowledge meant power and material wealth, became the scene of one of the attempts to embed the ideal of evangelical poverty into the social fabric of Latin Middle Ages, with traumatic and conflicting consequences which determined the further evolution of university structures.

\section{A Franciscan 'Team' of Masters}

Roger Bacon's reference to the role of Alexander as the one who set up the intellectual tools of the order and that 'exalted' it with respect to the previous reputation of the Minors, testifes to a new scholarly focus among the Franciscans. According to the Opus Minus, the social profile of Alexander, before he joined the order, perfectly matched the 'ideal type' of the university master: a quite learned cleric in charge of an ecclesiastical office, that of archdeacon, which combined prestige, power, and the wealth that came from the revenues connected to it. Despite the moral quality of Alexander - Roger notes that he was 'a good man' - the abandonment of this privileged social status following his joining of the order did not correspond to a renunciation of the practice of teaching theology based on the forms and contents of the master's activity. ${ }^{16}$ In a certain sense, what master Alexander brought to the order

15 Herbert Grundmann, 'Sacerdotium - Regnum - Studium: Zur Wertung der Wissenschaft im 13. Jahrhundert,' Archiv für Kulturgeschichte 34 (1952), pp. 5-21; John W. Baldwin, Masters, Princes and Merchants: The Social Views of Peter the Chanter and his Circle (Princeton: Princeton University Press, 1970); idem, 'Le context politique et institutional,' in Les Débuts de l'enseignement universitaire à Paris, eds. Verger and Weijers, pp. 17-26.

16 See Roger Bacon, Opus Minus, ed. Brewer, p. 325. 
in terms of wealth was not just his own personal prestige but mainly the capability to develop theological knowledge at the level required in the university. Through Alexander the Franciscans became acquainted with the combination of lecturing, questioning, and preaching, and with the custom of circulating ideas and doctrines not only through oral teaching but also through written texts.

The use of the Sentences as the basis for theological teaching and the acquaintance with the Gloss became part of the daily activity of the Parisian Franciscan masters along with a whole set of practices that were oriented towards teaching by elaborating a theology and towards elaborating a theology by teaching. ${ }^{17}$ This included also the habit of collecting the written results of this work, trying to give them an orderly and systematic shape that reflected the structure of the teaching activity and making these materials useful for other masters and students, or for the lectores in other Franciscan convents outside Paris. The intellectual prestige of Alexander, who according to Roger Bacon was the first theologian who institutionalized the practice of lecturing on the Sentences, certainly explains the key role he acquired in the Parisian convent as the one responsible for the organization of scholastic activities. $^{18}$

Bacon's critical remarks on the Parisian theological milieu and on the role attributed to Alexander offers some interesting indications regarding the learning activities of the Franciscans in Paris. His note concerning the authorship of the Summa ascribed to the master suggests that this vast and complex work was the result of the intellectual activity of several figures who belonged to the Franciscan order. More specifically, Bacon explicitly says that the Summa fratris Alexandri was put under the name of this master because of the prestige he had among his own religious brothers. In addition, he offers an indication concerning the origin of the materials collected in this work: the absence of any use of the disciplines and authorities which, according to Bacon, were crucial for the proper development of the biblical sciences, such as natural philosophy, mathematics, and metaphysics, matches the description he gave of the standards of the theological production of the time at the University of Paris. Therefore, the Summa belongs to a genre of works that were quite common within the university of the first half of the 13th century and consisted in the collection of the written fruits of the teaching activity of the masters. Alexander of Hales, who contributed significantly to shaping the intellectual life of the Friars Minor on the model of his own teaching experience, rapidly became the name which signified not just the activity of a single master, but rather the engagement of a team of well-trained theologians, probably including some of his pupils and coordinated by himself.

17 See Hubert P. Weber, 'The Glossa in IV Libros Sententiarum by Alexander of Hales,' in Mediaeval Commentaries on the 'Sentences' of Peter Lombard, ed. P. Rosemann (Leiden; Boston: Brill, 2010), vol. 2, pp. 79-109.

18 See Roger Bacon, Opus Minus, ed. Brewer, pp. 325-29. 
A significant witness to the introduction of this sort of working team in the Franciscan community in Paris is the composition of The Rule Commentary of the Four Masters, which was composed in 1241-42 in response to Haymo of Faversham's request for the Parisian masters of the order to explain the doubtful passages of the Franciscan Rule. ${ }^{19}$ The four theologians involved in this enterprise were Alexander of Hales, John of La Rochelle, Robert of La Bassée, and Odo Rigaldus, all based in the Franciscan convent in Paris. This group was probably at the origin of the composition of the Summa fratris Alexandri, which consists in a collection of the written products of the teaching activity not just of Alexander of Hales but also of the group of Franciscan theologians that recognized his intellectual authority. In this sense, Alexander is the name that conceals the work of a group of masters engaged in a reorganisation of the results of the teaching activity of the first generation of the Parisian masters of the Friars Minor.

Therefore, the Summa appears to be a collective work, whose composition comes from the contemporary editorial activity of at least two editors. ${ }^{20}$ In 1948 FrançoisMarie Henquinet published an article where he disclosed in advance the major conclusions that the Quaracchi editors reached on the issue of the authorship of the text. ${ }^{21}$ As Victorin Doucet soon after confirmed in the Prolegomena to the critical edition of the third book of the Summa, John of La Rochelle was the editor of the first and third parts of the text while another author, whom Henquinet called frater Considerans and could be Alexander himself, composed the second part of the work. ${ }^{22}$ The careful study of the text has confirmed this image of a simultaneous 'work in progress' of the first three parts of the Summa, evidencing the existence of important links and cross references between the first and the third parts and within the sections of the second part. This, together with the clear evidence that John of La Rochelle's writings are the direct source for large sections of parts I and III, contributes to explaining that the text originated from the practice of collecting notes and written materials from the Friars Minor present in Paris who taught theology.

Two other findings confirm this situation. First is the fact that the text of the Summa, included the first three books, with the exception of two later additions when Alexander and John died in early 1245. This suggests that these volumes were simultaneously composed and that Alexander himself could have had a role

19 See Expositio Quatuor Magistrorum super Regulam Fratrum Minorum (1241-1242): Accedit eiusdem Regulae textus cum fontibus et locis parallelis, ed. L. Oliger (Rome: Edizioni di Storia e Letteratura, 1950); Dieter Berg, Armut und Wissenschaft: Beiträge zur Geschichte des Studienwasens der Bettelorden im 13. Jahrhundert (Düsseldorf: Pädagogischer Verlag Schwann, 1977), pp. 72-73.

20 An essential analysis of the place of the Summa within the Franciscan intellectual milieu of the 13th century is provided by Lydia Schumacher, Early Franciscan Theology: Between Authority and Innovation (Cambridge: Cambridge University Press, 2019).

21 François-Marie Henquinet, 'Fr. Considerans, l'un des auteurs jumeaux de la Summa Fratris Alexandri primitive,' Recherches de théologie ancienne et médiévale 15 (1948), pp. 76-96.

22 Doucet, Prolegomena, pp. ccclx-cclxvii 
in this activity, and that his death, together with that of John of La Rochelle, effectively halted the compilation of the text. The second relevant piece of evidence is Alexander IV's bull De fontibus paradisii, which asked the Minors of the province of France to finish the Summa, which at that time did not include a volume on the sacraments. ${ }^{23}$ Dated to 7 October 1255, the papal document must also be read in the context of the clash between seculars and mendicants in Paris, following the publication, in that same year, of William of Saint-Amour's De periculis novissimorum temporum. Facing the challenge to the rights of the mendicants to hold chairs in theology, the bull strongly supported the Franciscans. As a close associate of Gregory IX, Pope Alexander sided with the Friars Minor in this polemical confrontation, acknowledging the Summa as a veritable witness to the capability and legitimacy of the Franciscan engagement in teaching theology. The papal text informs us that in 1255, the Summa was still unfinished, but it was renowned among the masters, a situation which suggests an early circulation of the first three volumes of the text.

\section{The Individual Books and the Whole Summa: The Multifarious Circulation of the Text}

The reference to the peculiarity of the process of the composition of the Summa provides some essential elements for dealing with the manuscript tradition of this work. In fact, it clarifies that this work belongs to the quite specific cultural environment which results from the convergence of the Franciscan religious and spiritual attitude and the structures and practices of the early 13th-century Parisian university. This remark helps to explain the multifarious circulation of the text which does not involve it as a whole but rather pertains to each of the parts of the Summa that started to be copied or used when their composition was still in progress.

The Quaracchi editors already noted that several chapters of the second part of the Summa, that is, the one composed by frater Considerans, are copied in the manuscripts Paris, Bibliothèque nationale de France 15652 and 15702. ${ }^{24}$ These two manuscripts collect a series of notes, records and texts dating from 1240-45 and stemming from the Parisian faculty of theology. In both of the manuscripts, the excerpts from the Summa cite quotations from William of Auxerre's Summa aurea, Philip the Chancellor's Summa de bono, and a large amount of reportationes of lectures on the Sen-

23 Doucet, Prolegomena, p. ccxxxviii. See also Robert Prentice, 'The De fontibus paradisii of Alexander IV on the Summa theologica of Alexander of Hales,' Franciscan Studies 5 (1945), pp. 350-51. 24 Doucet, Prolegomena, pp. cccxlv-cccliv; Marie-Dominique Chenu, 'Maîtres et bacheliers de l'Université de Paris vers 1240: Description du manuscrit Paris, Bibl. nat. lat. 15652,' Études d'histoire littéraire et doctrinale du XIII ${ }^{e}$ siècle: Première Serie (Paris: J. Vrin; Ottawa: Institut d'études médiévales, 1932), pp. 11-39. 
tences of the major Parisian masters of the early 1240s, as well as several of their disputed questions or quaestiones quodlibetales.

The two manuscripts were written by the same hand, and they are precious witnesses to the intellectual life at the Parisian faculty of theology in the fifth decade of the 13th century. The presence of chapters from the secunda pars among texts that refer to the teaching activity suggests that the contents of the Summa not only belong to the same environment but also circulated among the Parisian masters and were linked to the theological discussion and not just to the composition of a written text. $^{25}$ This latter enterprise was part of the whole intellectual life of its authors who were certainly engaged with teaching theology. The two manuscripts contain texts from the whole group of Parisian theologians in the early 1240s: Peter the Archbishop, Stephen of Puilly, John Pagus, Odo Rigaldus, Adam of Puteorumvilla, Bertrand of Bayon, Albert the Great, and Odo of Rosny, and John of Moussy, who all lectured on the Sentences in this period as bachelors; Walter of Chateau-Thierry, Peter Lamballe, Guerric of St Quentin, Alexander of Hales and John of La Rochelle, who were regent masters.

As regards the details of the manuscripts, Paris, Bibliothèque nationale de France, lat. 15702 is a copy of Peter Lombard's Sentences in whose margins the anonymous student recorded the teaching of the masters and bachelors whose lectures he attended and continued to collect materials in the notebooks which now form the manuscript 15652, so that the two manuscripts together offer a picture of the 'learning story' of this student of theology as well as of the teaching of this period, which was already strongly based upon the use of the Sentences as a textbook and as one of the pillars of the doctrinal development of the theological discourse.

The Summa fratris Alexandri is part of this cultural framework and quite significantly its excerpts cite the records of the Parisian masters in the margins of Peter Lombard's text in the manuscript 15702. The Quaracchi editors suggested that such a feature is a witness to the existence of a written early version of the Summa circulating in the 1240s in Paris. The excerpts from the Summa are placed in the margins of the second book of the Sentences and all belong to the second part of the Summa, the one focusing on the theological issue of creation, on the doctrine of the four causes, on angels and demons, on original sin, and on the role of the will. These notes in the manuscript 15702 have their continuation in those recorded in manuscript 15652, where the students took notes from the chapters of the second part of the Summa dedicated to the soul.

A closer look at the literary form of these quotes from the Summa offers some important information about the kind of 'text' with which the student could have dealt. In the tabula of the contents which introduces book two, where the distinctions dedicated to the creation of the human being are listed, the student copied the corresponding chapter of the Summa.

25 Doucet, Prolegomena, pp. cccli-ccclii. 
Paris, Bibliothèque nationale de France, SH II, PI, In3, Tr3, Q2, Ar1 (n. 315), p. 378 lat. 15702, fol. 56rb

De Summa Alexandri. Queritur cum dicaPotest autem quaeri secundum ordinem. tur Gen. I in operibus sex dierum: 'masculum et feminam creavit eos,' quare dixit ibid. II: 'Non est bonum esse hominem solum, faciamus ei adiutorium simile sibi.'

1. Primo propter quid dictum est: 'Non est bonum hominem esse solum,' cum iam dixerat: 'Masculum et feminam creavit eos.'

Dicendum quod primum dictum fuit per anticipationem, non quia facti fuerunt in opere sex dierum, sed ut ostenderetur quod cum uterque condebantur, ad imaginem Dei condebantur, quia imaginem †... $†$ uterque a Deo, non mulier a viro et hoc secundum spiritum qui a Deo conditus est.

(...)

Ad primum dicendum quod illud quod dicitur de masculo et femina, per anticipationem dictum est, non quia tunc simul facti sint in operibus sed dierum, sed ut ostenderetur quod tam masculus quam femina, cum condebantur, ad imaginem Dei condebantur, quam imaginem non accipiebat mulier a viro, sed uterque a Deo, secundum spiritum, qui a Deo conditus est.

In the beginning of the next folio, where the list of the contents of the second book of the Sentences mentions the issue of the vestigium, the student copied another disputed question from the Summa.

Paris, Bibliothèque nationale de France, SH II, In1, Tr1, S2, Q1, M2 (n. 34), p. 44 lat. 15702, fol. 57rb

Alexander. Hic queritur de vestigio, quod similiter refertur ad rationem cause, quia creatura dicitur vestigium creatoris.

Consequenter dicendum est de vestigio, quod similiter refertur ad rationem cauQuod dicitur multipliciter. Opus enim Dei dicitur multipliciter de operante et de operato; si vestigium dicitur multipliciter Dei, ergo vestigium multipliciter. sae: dicitur enim creatura vestigium ipsius Creatoris.

\section{(...)}

Ad primum sic obicitur quod multipliciter dicatur: 1. Opus enim dicitur multipliciter de ipso opere operante et de re operata; ergo, cum opus dicatur vestigium, vestigium dicetur multipliciter de ipsis actionibus et de rebus quae aguntur, cum de utrisque dicatur, sicut patet ex praemissis.

The Latin of the Parisian manuscript appears simpler than that of the Summa, showing how this latter is the result of a process of careful revision and the rearrangement of the language as well as the structure of the argument. These features can be explained as the result of a summary made from an early written version of a text 
that the Parisian student himself refers to as 'Alexander's Summa'. However, the literary and stylistic characteristics of the text seem closer to the record of an oral discourse than to a written text: the scholar could have attended a lecture where a written version of the second part of the Summa was used by the master in his lecture on Peter Lombard's text. This can explain the presence of these excerpts in the margins of the tabula of the second book of the Sentences.

Certainly, the manuscripts 15652 and 15702 of the Bibliothèque nationale witness to the existence of an early version of the Summa in the early 1240s, when Alexander of Hales was still teaching and was probably overseeing the collection of materials which would become the Summa fratris Alexandri. In addition, the contents and features of the textual excerpts of the two manuscripts highlight the close connection of the text with the living teaching activity of masters and bachelors. In fact, already in the years of its composition, the 'working version' of the Summa circulated and was used to lecture on the Sentences. Moreover, Peter Lombard's work was the very center of theological studies, and the contents of the Summa used as if they were part of an authoritative lecture on the Sentences, particularly the contents of the second book.

If we consider these remarks together with the fact that both the first and the third parts of the Summa were composed by John of La Rochelle, who mainly collected and reorganized materials which come form his own teaching activity, it is clear that these very early manuscripts of the text ascribed to Alexander of Hales directly link both its origin and early reception to the daily teaching of the Franciscan masters and bachelors in the early 1240s. Therefore, the composition of this vast and comprehensive collection of theological materials, organized under the leadership of Alexander of Hales, was deeply linked with lectures and disputes on the Sentences.

\section{The Summa and its Circulation through the University System of 'pecia' Manuscripts}

Henquinet and Doucet stressed the fact that the Summa started to circulate in the 1245 version. ${ }^{26}$ The two Parisian manuscripts examined here witness to an early circulation of the text according to a close link between teaching activity and the use of the contents of the Summa, so that before 1245, the composition of the text and its use by masters and bachelors were parts of one and the same intellectual praxis. At the moment of the death of both John of La Rochelle and Alexander of Hales ' a copy of the three existing parts of the Summa was already available for copyists. Among the manuscripts of parts one and two of the Summa, some still show the structure and contents of the 1245 text: they do not have the additions which accord-

26 Henquinet, 'Fr. Considerans,' pp. 95-96; Doucet, Prolegomena, pp. ccclxix-ccclxx. 
ing to the Quaracchi editors date from the intervention of William of Melitona, who also prepared much of the fourth part concerning the sacraments.

The section De missione visibili, at the very end of the first part of the Summa is omitted in the following manuscripts: ${ }^{27}$

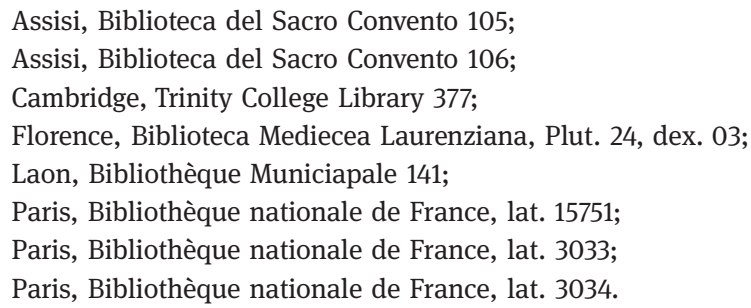

To this list can be added the manuscript Paris, Bibliothèque nationale de France, lat. 15750 which was copied by one and the same hand according to the 1245 version of the text and was later on integrated with a final 'cahier' containing the De missione visibili. ${ }^{28}$ At the very end of the manuscripts, Paris, Bibliothèque nationale de France, lat. 15751 and Firenze, Biblioteca Medicea Laurenziana, Plut. 24 dex. 03, 15th-century hands note that the text, ending with the words: '(...) licet magis proprie in gratiae prima donatione,' would continue in a following 'cahier' absent in these manuscripts. ${ }^{29}$

A similar situation concerns the much larger addition of the two treatises De corpore humano and De coniuncto humano, which are placed at the end of the first section of the second part of the Summa. Such additions are omitted in these manuscripts: $:^{30}$

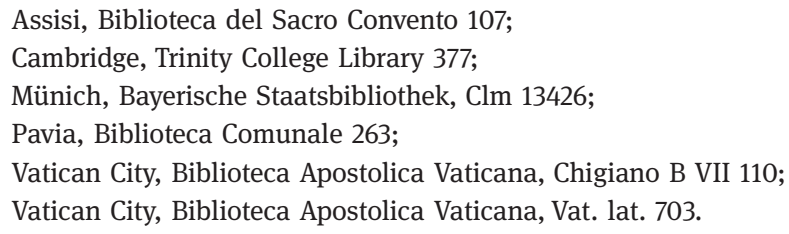

The manuscript Vienna, Österreichische Nationalsbibliothek 1384 explicitly attributes the long addition to William of Melitona (fol. 63r). In the case of both parts one and two of the Summa, there are pecia manuscripts which contain the 1245 version of the text: namely, the manuscripts Paris, Bibliothèque nationale de France, lat. 3033 for part one and the manuscript Assisi, Biblioteca del Sacro Convento 107

27 For a description of these manuscripts, see $S H$ I, Prolegomena, pp. xii-xxi; for the specific feature of the content of the enlisted manuscripts see ibid., p. xxiv.

28 See Doucet, Prolegomena, p. xvi.

29 See Doucet, Prolegomena, p. xix.

30 For a description of the following manuscripts see $S H$ II, Prolegomena, pp. $\mathrm{x}-\mathrm{xvii}$. 
for part two. ${ }^{31}$ Therefore, already the 1245, still incomplete version of the Summa was the subject of copying activity and of circulation based on the pecia system and the work of the Parisian stationarii.

Alexander IV's intervention in 1256 to support the work of a new 'team' of masters led by William of Melitona, whose aim was to complete the Summa, offers a precious chronological reference for both the setup of the fourth part of the text as well as for the completion of the additions to the first and second parts. Therefore, after the middle of the 13th century, the number of pecia manuscripts considerably increased for all the parts of the Summa. ${ }^{32}$ Its circulation in the University of Paris according to this specific system of copying manuscripts is connected with multiple ways of using the text, and still maintains some traces of the complex process through which it was assembled in the early 1240 s.

This is the case with the manuscript Vatican City, Biblioteca Apostolica Vaticana, Borgh. lat. 359, a mid-13th-century manuscript containing the first part of the Summa (fols. 2ra-116rb) and Bonaveture's De Scientia Christi et de Trinitate (fols. 117r132r). ${ }^{33}$ In the first folio a hand different from the copyist transcribed the index of the quaestiones of the Summa. The text of the work is then distributed into two columns, each of 60 lines, and presents rubrics added to all the paragraphs. The manuscript presents evidence of peciae and it can be linked with the university milieu. Several corrections are placed in the margins by a careful reader. Quite significantly, this is the only known manuscript of the Summa that does not ascribe the text to Alexander of Hales. Rather the rubricator, in the very beginning of the incipit explains that the manuscript contains the first part of an organized collection (summa) of disputed questions concerning Peter Lombard's Sentences whose presentation is ascribed to 'the Friars Minor'. Therefore, this manuscript does not link the Summa to the major intellectual figure of the Franciscan theological milieu of the time but rather stresses that its authorship is collective.

All the other manuscripts explicitly indicate Alexander of Hales as the figure linked with the composition of the text. The manuscript Florence, Biblioteca Medicea Laurenziana, Plut. 24 dex. 02, contains the first part of the Summa, attributing the text to Alexander. ${ }^{34}$ This manuscript, which belonged to the library of the Franciscan

31 On the two manuscripts see Giovanna Murano, Opere diffuse per exemplar et pecia (Turnhout: Brepols, 2005), p. 239.

32 See Murano, Opere diffuse per exemplar et pecia, pp. 238-44. Doucet and the Quaracchi editors record some indications of the pecia marks in their description of the manuscripts of the different parts of the Summa. However, in the 1930s and 1940s, the knowledge of the features of the pecia system as well as their relevance in the process of textual transmission was just at the beginning (Destrez's pivotal work dates to 1936; see Jean Destrez, La "pecia" dans les manuscrits universitaires du XIII e et du XIV viècle [Paris: J. Vautrain, 1935]). A careful re-examination of the manuscripts of the Summa allows us to reconsider the value of the manuscripts and their relevance with respect to the philological issues connected with the text and its historical development.

33 See SH I, Prolegomena, p. i; Murano, Opere diffuse per exemplar et pecia, p. 239.

34 SH I, Prolegomena, p. xii; Murano, Opere diffuse per exemplar et pecia, p. 238. 
convent of Santa Croce, has explicit signs of pecia in its margins, thus revealing that the exemplar from which it was copied was divided into 72 peciae. Another manuscript of the prima pars, Paris, Bibliothèque nationale de France, lat. 14529, is also the product of the pecia system but it comes from an exemplar with 42 peciae and is therefore different from the one of the Florentine manuscripts. ${ }^{35}$

A closer analysis of the pecia manuscripts of the Summa shows more specifically how the text was available at the stationarii. Even if the manuscript tradition refers to the Summa as one text divided into parts, each part of the text has its own manuscript tradition which involves the existence of different exemplars as well as further divisions of the text, to allow the copyists to easily deal with the enormous number of folios. While the first part of the Summa appears to be a unique textual unit throughout the manuscript tradition, the second part is divided in two textual units. This division was followed by the Quaracchi editors in their decision to publish the prima secundae and the secunda secundae of the Summa as respectively volumes II and III of the edition of the text.

As for the modern edition, also in the case of the medieval copyists, the decision to divide the second part and to create distinct exemplars for each textual unit was probably due to practical reasons and not to doctrinal issues, since the secunda pars is always presented as a whole. The manuscript Paris, Bibliothèque Mazarine 784 contains the whole second part of the Summa, but it is the result of the reunification of the copies of the prima secundae and of the secunda secundae: there are, in fact, explicit indications of peciae which differently number each of the two parts. ${ }^{36}$ Therefore, the prima secundae (fols. 1ra-162va) is copied from an exemplar of 95 peciae and at fol. 159rb shows the mark of the beginning of the last pecia. The secunda secundae (fols. 165ra - 362vb) starts after some blank folios and refers to a second series of 95 peciae. Quite interestingly, the manuscript of the Mazarine Library records also the name of one of the copyists. At fol. $183 \mathrm{r}$ in the lower margin, a note explains: 'Hugo de Biston. incepit in xiii ${ }^{a}$ pec. secunde partis.' The same name is mentioned again at fol. 212va.

A similar division in multiple textual units, each one dependent on an exemplar, is evident in the case of both the third and the fourth parts of the Summa. The first unit of the third part, which includes the section on the Incarnation, depends on an exemplar of 38 peciae; the second textual unit, containing the treatise on laws, depends on an exemplar of 78 peciae; the third textual unit, which includes the treatise on grace, refers to a division in 15 peciae; the fourth textual unit contains the treatise on virtue and comes from an exemplar of 11 peciae.

Even if a large number of manuscripts present the third part of the Summa as a whole, it is possible to identify the different textual units and the series of peciae from which they come.

35 SH I, Prolegomena, pp. xv-xvi; Murano, Opere diffuse per exemplar et pecia, p. 239.

36 SH II, Prolegomena, p. xv; Murano, Opere diffuse per exemplar et pecia, pp. 239-240. 


\begin{tabular}{|c|c|c|c|c|}
\hline Manuscript & $\begin{array}{l}\mathrm{I}^{\mathrm{a}} \mathrm{III}^{\mathrm{ae}} \\
(38 \text { peciae })\end{array}$ & $\begin{array}{l}{ }^{\prime I^{\mathrm{a}}} \mathrm{II}^{\mathrm{ae}} \\
(78 \text { peciae })\end{array}$ & $\begin{array}{l}\mathrm{III}^{\mathrm{a}} \mathrm{III}^{\mathrm{ae}} \\
(15 \text { peciae })\end{array}$ & $\begin{array}{l}\text { IV }^{\mathrm{a}} \text { III }^{\mathrm{ae}} \\
\text { (11 peciae) }\end{array}$ \\
\hline $\begin{array}{l}\text { Florence, BML, } \\
\text { Plut. } 24 \text { dex. } 05\end{array}$ & fols. $5 \mathrm{ra}-70 \mathrm{v}$ & fols. $71 \mathrm{ra}-216 \mathrm{vb}$ & fols. $217 \mathrm{ra}-244 \mathrm{vb}$ & fols. $245 \mathrm{ra}-265 \mathrm{ra}$ \\
\hline $\begin{array}{l}\text { Paris, Bibl. Mazar- } \\
\text { ine, } 785\end{array}$ & fols. 1 ra-59ra & fols. $55 \mathrm{ra}-158 \mathrm{ra}$ & fols. 159ra-178rb & fols. 179ra-191va \\
\hline $\begin{array}{l}\text { Paris, BnF, } \\
\text { lat. } 15328\end{array}$ & fols. $1 \mathrm{ra}-43 \mathrm{rb}$ & fols. $43 r b-136 r b$ & fols. $137 \mathrm{ra}-154 \mathrm{va}$ & fols. $154 v a-169 v b$ \\
\hline $\begin{array}{l}\text { Todi, Biblioteca } \\
\text { Comunale } 87\end{array}$ & fols. $5 r a-42 r b$ & fols. $43 \mathrm{ra}-134 \mathrm{vb}$ & fols. $134 \mathrm{vb}-152 \mathrm{rb}$ & fols. $152 \mathrm{rb}-164 \mathrm{rv}$ \\
\hline Vienna, ÖNB 1503 & fols. $5 r a-69 v b$ & fols. $71 \mathrm{ra}-225 \mathrm{vb}$ & fols. $226 \mathrm{ra}-258 \mathrm{rb}$ & - \\
\hline
\end{tabular}

Some other manuscripts suggest also the independent circulation of each textual unit. For instance, the manuscript Paris, Bibliothèque nationale de France, lat. 3037 contains only the first unit of the third part, that is, the treatise on the Incarnation. ${ }^{37}$ By contrast, the manuscript Paris, Bibliothèque nationale de France, lat. 3036 collects a copy of the other three units of the tertia pars: II $^{\mathrm{a}} \mathrm{III}^{\mathrm{ae}}$ fols. $1-111$; III $^{\mathrm{a}} \mathrm{III}^{\mathrm{ae}}$ fols. 113-133; IV ${ }^{\mathrm{a}}$ III ${ }^{\mathrm{ae}}$ fols. $133-147 .^{38}$

The fourth part of the Summa, composed under the supervision of William of Melitona, is divided into three textual units: the first contains the study of the notion of the sacrament and the section on baptism and confirmation; the second one contains the section on Eucharist; the third unit contains the rest of the fourth part. Already in this case the manuscript tradition presents a clear distinction between the copying of the three exemplars into which the quarta pars has been divided.

\begin{tabular}{|c|c|c|c|}
\hline Manuscript & $\begin{array}{l}\mathrm{I}^{\mathrm{a}} \text { IV } \\
(54 \text { peciae })\end{array}$ & $\begin{array}{l}\text { II }^{\mathrm{a}} \text { IV }^{\mathrm{ae}} \\
(17 \text { peciae })\end{array}$ & $\begin{array}{l}\text { III }{ }^{\mathrm{a}} \mathrm{IV}^{\mathrm{ae}} \\
(?)\end{array}$ \\
\hline $\begin{array}{l}\text { Cesena, Biblioteca Malatestiana, } \\
\text { D.XV.1 }\end{array}$ & fols. 1 ra-87ra & fols. $87 \mathrm{ra}-117 \mathrm{ra}$ & \\
\hline Cambrai, BM 433 & fols. $1 \mathrm{ra}-111 \mathrm{ra}$ & fols. 111ra-152ra & fols. $152 \mathrm{ra}-211$ \\
\hline $\begin{array}{l}\text { Florence, BNCF, Conv. Soppr. } \\
\text { I.3.9 }\end{array}$ & fols. $121 \mathrm{ra}-194 \mathrm{vb}$ & fols. $195 \mathrm{ra}-228 \mathrm{vb}$ & \\
\hline Paris, BnF, lat. 15328 & fols. 179ra-266vb & fols. $267 \mathrm{ra}-347 \mathrm{va}$ & fols. $247 v a-446 r b$ \\
\hline Reims, BM 472 & fols. $1-116 v$ & fols. $117 r-218 r$ & fols. $218 r-235$ \\
\hline
\end{tabular}

As it was involved in the pecia system of copying, the Summa was rapidly spread within the university, becoming a text available for both masters and students, and more importantly a text used by theologians. Manuscripts of the Summa are, in fact, present in the library of the College Sorbonne, such as the series Paris, Bibliothèque nationale de France, lat. 15334-15336, and Paris, Bibliothèque nationale

37 Doucet, Prolegomena, pp. xxiv-xxv; Murano, Opere diffuse per exemplar et pecia, p. 241. 38 Doucet, Prolegomena, p. xxiv; Murano, Opere diffuse per exemplar et pecia, pp. 241-43. 
de France, lat. $15329-15333 .{ }^{39}$ Both these two groups of manuscripts were part of editorial projects on the Summa, in specific, one and the same hand copied the manuscripts 15334-15336. The same happened with the manuscripts Paris, Bibliothèque nationale de France, lat. $15750-15753,{ }^{40}$ which contain the whole Summa and belonged to one of the major masters of theology in Paris, Gerard of Abbeville. This secular master possessed a second copy of the Summa, namely, the one distributed in the two manuscripts Paris, Bibliothèque nationale de France, lat. 15327-15328. ${ }^{41}$

The Summa was thus part of the cultural milieu of the University of Paris, but it was present also in the libraries of the convents of the Franciscan Order. Manuscripts of the Summa were preserved in the library of the convent of Santa Croce from the end of the 13th century, while the early 14th-century catalogue of the library of the convent of Saint Francis in Pisa lists a copy 'in four volumes' of the Summa. Moreover, a copy of 'the whole Summa of Alexander in four volumes' was present in the library of the Dominican convent in Pisa from $1278 .{ }^{42}$ In that year, the friar Proinus, son of the lord Orlandini de Fabro, gifted his own library to the convent. Proinus had done his own theological studies in Paris and was of the same age of Thomas Aquinas, and with Aquinas had been made general preacher of the order on the occasion of the general chapter of Naples in 1260. The wealth of his father allowed Proinus to collect a private library, which reflects the theological and, more broadly speaking, religious culture of a learned Dominican friar who had received an education in theology at Saint Jacques and later on lectured on theology in some of the major studia of the order. Quite significantly, Proinus' list includes Peter Lombard's Sentences. Albert the Great's writings, philosophical texts, Aquinas' commentary on the Sentences, and the reference works in canon law.

The presence of copies of the Summa in specific places such as the library of the Collège Sorbonne or in private libraries of masters such as Gerard of Abbeville and of a famous lector and preacher as the Dominican Proinus di Orlandini de Fabro, confirms the picture that emerges from a rapid survey of the manuscript tradition: the existence of an important circulation of the Summa within the intellectual elite that was educated in the university or in the studia generalia.

39 SH II, Prolegomena, pp. xi-xii.

40 SH I, Prolegomena, p. xvi; Doucet, Prolegomena, pp. xxv, cccxli; Murano, Opere diffuse per exemplar et pecia, p. 239.

41 SH I, Prolegomena, pp. xiii, xiv; Murano, Opere diffuse per exemplar et pecia, pp. 241, 244. On the private library of Gerard of Abbeville and its attachment to the College de Sorbonne, see Palémon Glorieux, 'Bibliothèque de Maîtres parisiens: Gérard d'Abbeville,' Recherches de théologie ancienne et médiévale 36 (1969), pp. 148-83; Richard-H. Rouse, 'The Early Library of the Sorbonne,' Scriptorium 21 (1967), pp. 42-71, 227-251. See also Stephen M. Metzger, Gerard of Abbeville, Secular Master, on Knowledge, Wisdom and Contemplation, 2 vols (Leiden; Boston: Brill, 2017).

42 A digital edition of Proinus' list is available at http://www.e-theca.net/emiliopanella/pisa/ croni50.htm. See also Ferdinand Pelster, 'Die Bibliothek von Santa Caterina zu Pisa, eine Büchersammlung aus den Zeiten des hl. Thomas von Aquin,' Xenia Thomistica 3 (1925), pp. 249-80. 


\section{The Plurality of Manuscripts and their Multifarious Circulation}

More than two centuries after the completion of the text, the different forms that the Summa fratris Alexandri assumed in the early printed editions from the second half of the 15th century mirrored the complex process of its construction and circulation. The two Parisian manuscripts, BnF lat. 15652 and 15702 offer an interesting view of what can be identified as the very first phase in the history of the Summa and its circulation between 1240 and 1245 . They show how the writing of this text was organized by a team of masters and bachelors under the name of Alexander of Hales, who was himself directly involved in creating this collection of materials and could be the author of the secunda pars.

Certainly, the construction of the Summa, whose first three parts were collected simultaneously in the early 1240s, was directly linked with the teaching activity of the Franciscan masters in Paris. A confirmation of this comes from the presence among the sources of the first and third parts of John of La Rochelle's disputed questions, which mirror the oral form of the master's teaching and whose contents were rearranged in a more literary form in the Summa. The use of the secunda pars as a gloss on the second book of the Sentences further confirms that the materials that became part of the Summa were used in teaching by oral quotations or by reference to early manuscript copies of the text.

The death of both John of La Rochelle and Alexander of Hales in 1245 left the work unfinished but did not stop its circulation. The early version of the Summa was involved in the pecia system of copying, initiating an initial line in the manuscript tradition which preserved the 1245 version of the text marked by the absence of the treatise De missione visibili in part one, and of the treatises De corpore humano and De coniuncto humano as well as of the whole fourth part. After Alexander IV's intervention, William of Melitona and the new team he led finalized the collection of the materials that form the Summa fratris Alexandri and inserted this new version in the university milieu.

Roger Bacon, in his quite polemical style, adds a note to his critical account on Alexander's work: 'In addition, he says, an exemplar [of the Summa] putrefies among the friars and lays untouched and not read in these times. ${ }^{43}$ Despite the unfriendly judgment of the Doctor Mirabilis, an analysis of the manuscript tradition shows that the four parts of the Summa were widely available around the third quarter of the 13th century as one of the relevant texts for the intellectual activity of the intellectual milieu of the universities and the studia of the mendicant orders. In this period the Summa became part of the group of writings available at the stationarii, but more im-

43 Roger Bacon, Opus Minus, ed. Brewer, p. 327: 'Immo exemplar apud fratres putrescit et jacet intactum et invisum his temporibus.' 
portantly, it was included in a sort of 'ideal library' which was shared by the theologians in the second half of the 13th century. This explains its presence not only in the libraries of institutions such as the Collège Sorbonne but also in the private manuscript collection of a master such as Gerard of Abbeville or in that of an important figure of the Dominican order in Italy such as Proinus.

This multifarious circulation of the text is consistent with its influence on contemporary theological debates, and its features clearly emerge from the manuscript tradition. This shows the diverse form of the reception of the text and its perception throughout the centuries as a unified work ascribed to Alexander of Hales. Such a sense of the coherence of the Summa probably comes from the very origin of the text, which was the result of a process within which different activities such as teaching, thinking and editing written texts were all involved together. A first survey of the manuscript tradition seems to suggest that throughout medieval centuries and still in the late 15th century, the Summa was seen as a series of parts which were distinct but not separated. The contents of this text, under the prestigious name of Alexander of Hales, remained important in theological discourse, highlighting the practices of lecturing, disputing, and elaborating new doctrines that dominated at the time, transforming the status of the Summa itself into that of a 'classic' of 13th-century scholastic theology. 